\title{
A STUDY OF PREVALENCE OF OVERWEIGHT AMONG DRIVERS AND CONDUCTORS OF PURNEA- KATIHAR, KOSI DIVISION, KATIHAR
}

\author{
Iqbal Shahid ${ }^{1}$ Prawin Chandra²
}

${ }^{1}$ Assistant Professor, Department of Community Medicine, Katihar Medical College, Katihar. ${ }^{2}$ Assistant Professor, Department of Community Medicine, Katihar Medical College, Katihar.

\begin{tabular}{l}
\hline ABSTRACT \\
BACKGROUND \\
Overweight has become a major disorder affecting a large population more than any other disease in the world. The aim is to study \\
the prevalence of overweight and obesity among drivers and conductors of Purnea-Katihar and to compare the prevalence of \\
overweight among them.
\end{tabular}

\section{MATERIALS \& METHODS}

Randomly selected 365 drivers and 370 conductors were personally interviewed using predesigned, pretested structured questionnaire, physical examination was done to measure height, weight, waist circumstances and hip circumstances. Body Mass Index, waist circumstances and waist-hip ratio were used to assess control and overweight cases, and rates were calculated. Chisquare test was used to test the difference of prevalence between drivers and conductors.

\section{RESULTS}

The study showed that in drivers $43.3 \%$ were overweight, $22.2 \%$ were obese and $23.6 \%$ were having a waist circumference $>102$ $\mathrm{cm}$. Among conductors, $28.1 \%$ were overweight, $16.2 \%$ were obese and $18.1 \%$ were having a waist circumference of $>102 \mathrm{~cm}$.

\section{CONCLUSION}

The prevalence of overweight was high among drivers compared to conductors. The differences were found to be statistically significant, considering the high prevalence of overweight among drivers and conductors, and necessary preventive measures need to be promoted. The control of overweight by dietary changes and increase in physical activity is recommended.

\section{KEYWORDS}

Overweight, Drivers, Conductors.

HOW TO CITE THIS ARTICLE: Iqbal S, Chandra P. A study of prevalence of overweight among drivers and conductors of PurneaKatihar, Kosi division, Katihar. J. Evolution Med. Dent. Sci. 2017;6(30):2451-2454, DOI: 10.14260/Jemds/2017/529

\section{BACKGROUND}

Overweight or obesity is caused by abnormal growth of adipose tissue due to enlargement of fat cell or an increase in number of fat cells. Being overweight is a chronic disease that is increasing in prevalence and is posing a serious risk for development of various diseases like hypertension, diabetes mellitus, hyperlipidaemia, coronary heart disease, gall bladder disease, osteoarthritis and certain forms of cancer.(1) In the World Health Report of April 25th 2003, WHO identifies overweight and its complications among the top 10 global risks affecting today's disease and disability which accounts for $40 \%$ of Global Death. $(2,3)$

Overweight is the fifth leading risk of global deaths. Worldwide, obesity has more than doubled since 1980 . In 2008, more than 1.4 billion adults, 20 years and old, were overweight. Of these, over 200 million men and nearly 300 million women were obese. In 2012, more than 40 million children under 5 years of age were overweight. Once considered a high income country problem, overweight and obesity are now raising in low and middle income

Financial or Other, Competing Interest: None.

Submission 05-01-2017, Peer Review 30-03-2017,

Acceptance 06-04-2017, Published 13-04-2017.

Corresponding Author:

Iqbal Shahid,

Husainabad, Choudhri Mohalla,

Katihar, Bihar-859105

E-mail: shahidiqbalkmc@gmail.com

DOI: $10.14260 /$ jemds $/ 2017 / 529$ countries, particularly in urban setting. Close to 30 million overweight children are living in developing and 10 million in developed countries.(4) In India, the noncommunicable risk factor phase 2 was carried out in the year 2007-2008, in states of Andhra Pradesh, Kerala, Madhya Pradesh, Maharashtra, Tamil Nadu, Uttarakhand and Mizoram. The survey shows high prevalence of overweight in all age groups except in 15-24 years group. Overweight prevalence was higher among females and males and in urban areas than rural areas, low prevalence was recorded among people with lower level of education (illiterate and primary level) and in people whose occupation was connected with agriculture or manual work. (5)

In India, 1.3 percent males and 2.5 percent females aged more than 20 years were obese in the year 2008.(6) Obesity can occur at any age and generally increases with age. Infants with excessive weight gain have an increased incidence of obesity in later part of life.(7) Weight control is widely defined as approaches to maintaining weight within a healthy (i.e. normal or acceptable) range of body mass index of 18.5 to $24.9 \mathrm{Kg} / \mathrm{m}^{2}$ throughout adulthood (WHO expert committee 1995).It should also include prevention of weight gain of more than $5 \mathrm{Kg}$ in all people. In those who are already overweight, a reduction of 5-10 percent of body weight is recommended as an initial goal.(8)

The bus drivers and conductors are one such group who are at a risk of developing overweight due to nature of their profession. They form one of the largest groups of employing personnel of different caste and creed, various age groups, 
subjected to severe stress and strain, having irregular hours of duty, having habits like smoking and alcohol, etc. Once they develop overweight they are prone to develop hypertension, coronary heart disease and stroke putting them and their road users at risk. Hence, there is a need to enquire into the prevalence of overweight in the community setting of bus drivers and conductors. It was against this backdrop of importance of overweight, coupled with lack of community based studies in this subject in bus drivers and conductors we were prompted to take up the present study.

The aims and objectives of the study were to see and measure the prevalence of overweight among bus drivers and conductors of Purnea-Katihar in Kosi Division, Katihar.

\section{MATERIALS AND METHODS}

A cross sectional study was undertaken to see the prevalence of overweight among bus drivers and conductors of PurneaKatihar in Kosi Division in Katihar. The study was conducted for a period of one year from Oct. 2015-Sep. 2016. The prevalence of overweight among bus drivers and conductors of Purnea-Katihar in Kosi Division, Katihar was not known to calculate the sample size, the prevalence was supposed to be $50 \%$ with a $10 \%$ relative error of prevalence. The sample size arrived at was 400 i.e. 400 drivers and 400 conductors, However, 365 drivers and 370 conductors participated in the study. All were male.

The study participants were personally interviewed using predesigned and pretested structured questionnaire. The instruments used in the study included height stand (accurate up to $1 \mathrm{~cm}$ ), measuring tape (accurate up to $1 \mathrm{~cm}$ ), weighing machine (accurate up to $0.5 \mathrm{~kg}$ ). All the instruments and techniques were initially standardised during pilot study and were regularly standardised throughout the period of data collection. The weighing machine was also checked and corrected, if required after every $10^{\text {th }}$ reading during the study period. Body Mass index [BMI - Weight] in $\mathrm{Kg} /$ height in metre $)^{2}$ ] was used to assess overweight. Waist circumference and Waist-Hip Ratio (WHR) were used to assess central obesity. According to WHO criteria, overweight is defined as BMI $>25$, obesity is defined as $\mathrm{BMI}>30$ and overweight is defined as WHR $>1$ and waist circumference > $102 \mathrm{~cm}$. Overweight reflects an increased risk for cardiovascular disease and other metabolic complications. ${ }^{(1)}$

The medical ethics committee of KMC has gone through the report and considered the proposed research work. The committee has no objection if the research work is done after the consent is taken from the study population. Data was analysed using the software SPSS 10.0.1 for windows. Summary figures like rates were calculated, Chi-square test was used to test the difference of prevalence of overweight between drivers and conductors.

\section{RESULTS}

Drivers 400 and conductors 400 were selected randomly, but only 365 drivers and 370 conductors participated in the study.

The minimum age of the study participants was 26 years for drivers and 25 years for conductors and maximum age was 57 years for drivers and 55 years for conductors. All the study participants were male. Most of the drivers (36.7\%) and conductors (34.9\%) were in the age group of $40-49$ years.

The present study showed that $43.3 \%$ of drivers and $28.1 \%$ of conductors were overweight. This difference among drivers compared to conductors was found to be statistically significant. (Table 1).

\begin{tabular}{|c|c|c|}
\hline Status BMI & \multicolumn{2}{|c|}{ No. of Cases } \\
\hline & Drivers $(\mathrm{n}=365)$ & $20(5.4 \%)$ \\
\hline Underweight $(<18.5)$ & $17(4.7 \%)$ & $246(66.5 \%)$ \\
Normal weight $(18.5-24.99)$ & $190(52.0 \%)$ & $104(28.1 \%)$ \\
Overweight $(>25)$ & $158(43.3 \%)$ & conductor $(\mathrm{n}=370)$ \\
\hline \multicolumn{2}{|c|}{ Table 1. Distribution of Cases Accordingly to BMI } \\
\hline \multicolumn{2}{|c|}{}
\end{tabular}

The prevalence of overweight according to WHR>1 was $21.1 \%$ among drivers and $14.1 \%$ among conductors and this difference was also statistically significant $(\mathrm{p}=0.012)$ (Table-2).

\begin{tabular}{|c|c|c|}
\hline Waist-Hip Ratio & No. of Cases \\
\hline \multirow{3}{*}{$<1$} & Drivers $(\mathrm{n}=365)$ & Conductors $(\mathrm{n}=370)$ \\
\cline { 2 - 3 } & $279(76.4 \%)$ & $303(81.9 \%)$ \\
\cline { 2 - 3 } & $86(23.6 \%)$ & $67(18.1 \%)$ \\
\hline \multicolumn{2}{|c|}{$\mathrm{X}^{2}=6.296 ; \mathrm{df}=1 ; \mathrm{p}=0.012$} \\
\hline \multicolumn{2}{|c|}{ Table 2. Distribution of Cases Accordingly to Waist-Hip Ratio } \\
\hline
\end{tabular}

Similarly, the prevalence of central obesity according to waist circumference (waist- circumferences $>102 \mathrm{~cm}$ ) was $23.6 \%$ among drivers and $18.1 \%$ among conductors. This difference among drivers compared to conductors was also statically significant $(\mathrm{p}=0.069)$ (Table-3).

\begin{tabular}{|c|c|c|}
\hline Waist Circumference & \multicolumn{2}{|c|}{ No. of Cases } \\
\hline \multirow[b]{2}{*}{$\begin{array}{l}<102 \mathrm{~cm} \\
>102 \mathrm{~cm}\end{array}$} & Drivers $(n=365)$ & Conductors $(\mathrm{n}=370)$ \\
\hline & $\begin{array}{c}279(76.4 \%) \\
86(23.6 \%)\end{array}$ & $\begin{array}{c}303(81.9 \%) \\
67(18.1 \%)\end{array}$ \\
\hline \multicolumn{3}{|c|}{$\mathrm{X}^{2}=3.315 ; \mathrm{df}=1 ; \mathrm{p}=0.069$} \\
\hline \multicolumn{3}{|c|}{ Table 3. Distribution of Cases of According to Waist Circumference } \\
\hline
\end{tabular}


Among the drivers and conductors who were obese, most of them were having a mixed diet.

\section{DISCUSSION}

The present study revealed that the prevalence of overweight and obesity was $43.3 \%$ and $22.2 \%$ respectively in drivers and $28.1 \%$ and $16.2 \%$ respectively in conductors. The prevalence in this study is higher as compared to various previous studies ${ }^{(9-14)}$ done on general population groups. These studies showed a prevalence ranging from $7 \%$ to $34 \%$. According to the World Health Organisation (WHO), nearly 20 to $40 \%$ of adult population are affected by overweight.(1)

In a study conducted in Taiwan by Wang and Lin,(15) the prevalence of overweight was $9.6 \%$ among urban bus drivers which is less compared to this study. However, they had also observed an increased prevalence of overweight among bus drivers than the other skilled workers.

Overweight, defined by WHR $>1$ and waist circumferences $>102 \mathrm{~cm}$ was seen in significant number of drivers and conductors. A WHR $>1$ was seen among $21.1 \%$, drivers and $14.1 \%$ of conductors. Waist circumference $>102$ $\mathrm{cm}$ was seen in $23.6 \%$ of drivers and $18.1 \%$ of conductors. Overweight is an independent risk factor for coronary heart disease (CHD).(1,16,17) This occurs both through altered secretion of adipocyte-derived biologically active substances (adipokines) including free fatty acids, adiponectin, interleukin-6, tumour necrosis factor alpha, plasminogen activator inhibitor-1 and through exacerbation of insulin resistance and associated cardiometabolic risk factor.(18)

In a study(19) conducted in north of Iran, among urban population aged 20-70 years, the prevalence of overweight was found to be $28.3 \%$ which is comparable to this study.

In this study, it was also seen that the prevalence of overweight as well as obesity was higher among drivers compared to the conductors and this difference was statistically significant. Hence, drivers are more prone to develop CHD and metabolic complications. Overweight bus drivers are more likely to become fatigued than nonoverweight drivers. As they spend long hours on roads, they put themselves and their road users at risk of road traffic accidents.(20)

\section{CONCLUSION}

Overweight is quite prevalent among bus drivers and conductors, especially more among drivers. BMI is a simple and effective way to screen overweight and obese people. Both WHR and waist circumference are independent tools for measurement of overweight. Timely necessary measures need to be promoted to prevent their progression and complications associated with obesity. Measures to increase physical exercise both at home and at work place should be undertaken, and screening programmes to detect diabetes and hypertension should be undertaken among the overweight study participants.

\section{Recommendations}

The control of overweight by weight reduction- this can be achieved by dietary changes both at home and Dhaba (Hotel Road Side), and increased physical activity both at home and at work place should be undertaken.

a. Dietary Change- The proportion of energy dense foods such as simple carbohydrates and fats should be reduced; the fibre content in the diet should be increased through the consumption of common un-refined foods with adequate levels of essential nutrients in the low energy diets.

b. Increased physical activity-Regular physical exercise is the key to increased energy expenditure.

\section{Limitations}

Indirect and imperfect measurement does not distinguish between body fat and lean body mass. Increased waist-to-hip ratio can be caused by increased abdominal fat or decrease in lean muscle mass around the hips.

\section{REFERENCES}

[1] Park K. Park's Text book of preventive and social medicine. 23rd edn. Jabalpur Banarsidas Bhanot 2015:397-401.

[2] World Health Organisation. http://www.searo.who.int India/media centre/events/2016/en/International diabetes Federation.

[3] Deitel M. Overweight and obesity worldwide now estimated to involve 1.7 billion people. Obese surg 2003;13(3):329-30.

[4] WHO. Obesity and overweight, fact sheet No: 311 2014.

[5] Govt. Of India 2011. National health profile 2011, ministry of health and family welfare, New Delhi.

[6] WHO. World Health Statistics 2014.

[7] Charney E, Goodman HC, McBride M, et al.Childhood antecedents of adult obesity. Do chubby infants become obese adults? N Eng J Med1976;295(1):6-9.

[8] WHO. International agency for research on cancer. IARC handbook of cancer prevention, weight cannot and physical activity. IARC Press by on 2002.

[9] Tiwari-R, Shrivastava D, Gour N. A cross sectional study to determine prevalence of obesity in high income group of Gwalior city. Indian J community Med 2009;34(3):218-22.

[10] Zargar AH, Masoodi SR, Laway BA, et al. Prevalence of obesity in adults-an epidemiological study from Kashmir valley of Indian subcontinent. J Assoc physicians India 2000;48(12):1170-4.

[11] Afridi AK, Khan A. Prevalence and etiology of obesityan overview. Pak J Nut 2004;3(1):14-25.

[12] Al-Mahroos F, Al-Roomi K. Obesity among adult Bahraini population: impact of physical activity and educational level. Ann Saudi Med 2001;21(3-4):183-7.

[13] Abbas M, Khan A, Khattak MM. prevalence of obesity in male in relation to dietary intake and physical activity level. Pak j Nutr 2003;2(4):234-7.

[14] Khan A, Afridi AK, Safdar M. Prevalence of obesity in employees of universities health and research institutions of Peshawar. Pak J Nutr 2003;2(3):182-8.

[15] Wang PD, Lin RS. Coronary heart disease risk factors in urban bus drivers. J Public Health 2001;115(4):2614.

[16] Gopalan C. Obesity in the Indian urban middle class. Bull Nutr Foundation India 1998;19:1-5.

[17] Oppert JM, Charles MA, Thibult N, et al. Anthropometric estimates of muscle and fat mass in relation to cardiac mortality in men: the Paris prospective study. Am J Clin Nutr 2002;75(6):1107-13. 
[18] Jean-Pierre D. Abdominal obesity, the most prevalent cause of the metabolic syndrome and related cardiometabolic risk. Turkiye Klinileri J Med Sci 2009;29:826-32.

[19] Hajian-Tilaki KO, Heidari B. Prevalence of obesity, central obesity and the associated factors in urban population aged 20-70 years, in the north of Iran: a population based study and regression approach. Obese Rev 2007;8(1):3-10.
[20] Wiegend DM, Hononmski RJ, McDonald SE. Commercial drivers' health: a naturalistic study of body mass index, fatigue, and involvement in safety critical events. Traffic inj Prev 2009;10(6):573-9. 